\title{
A review of soil erosion modeling by R/USLE in Morocco: Achievements and limits
}

\author{
Mohamed Manaouch ${ }^{1, *}$, Anis Zouagui ${ }^{2}$, and Imad Fenjiro ${ }^{1}$ \\ ${ }^{1}$ Ibn Tofail, FLSH, Geographical Department, 14000 Kenitra, Morocco \\ ${ }^{2}$ CNESTEN Center, Conservatory management of water and soil, 10001 Rabat, Morocco
}

\begin{abstract}
Soil erosion is a major cause of land degradation. It can be estimated with several models, such as empirical, conceptual and physical based. One of the empirical models used worldwide nowadays for soil erosion assessment is the Universal Soil Loss Equation (USLE) and its updated form, the Revised Universal Soil Loss Equation (RUSLE). In Morocco, this model is being used to assess and quantify soil loss by water erosion. In spite of this, it was noted that limited studies employed correctly this important tool. The goal of this review paper was to identify potential usage of R/USLE models in Morocco. This was done by evaluating the conducted studies concerning these models and main gaps and challenges were determined accordingly. Improvement options and future requirements for using R/USLE models were recommended. In order to assess the statues of the R/USLE models applications, the 56 published documents related to R/USLE models conducted in Morocco during the first use till 2020 were collected and reviewed. These publications covered five main areas. The main benefits as well as gaps of the conducted studies were discussed for each area. Current concerns, need of future studies as well as related recommendations and suggestions were also presented.
\end{abstract}

\section{Introduction}

In view of the increasing awareness concerning soil erosion issues worldwide, several models were developed to assess the environmental impacts and assist in mitigating and minimizing the negative impacts.

Universal Soil Loss Equation is one of models developed for these issues. USLE was the first empirical model developed by Wischmeier and Smith. It was introduced for the first time to the research community in the late 1978s, then developed by many researchers.

Very important improvements were developed for upgrading the USLE to the Revised Universal Soil Loss Equation. The RUSLE retains the same form equation of the USLE, but it has updated values for the USLE factors by using new relationships and additional values for rangelands and subsurface drainage to understand the support practice impact assessment phase and its relation to reduce soil erosion rate. RUSLE is employed to estimate the environmental impacts of water erosion considering all inputs from raw factors, rainfall, land cover, topography, erodibility and support practices.

Nowadays many researches have adopted the soil erosion modeling and R/USLE model's applications are being conducted worldwide by researchers. In Morocco, in spite of the increasing awareness and concern about soil erosion issues, there are limited studies on the use of $\mathrm{R} / \mathrm{USLE}$ models as a tool for soil erosion assessment. This review article will attempt to evaluate the current status of the R/USLE applications conducted in Morocco and to identify potential usage of R/USLE models in future applications. Thus, the main objectives are to identify conducted R/USLE studies, determine main gaps and challenges in conducted R/USLE studies and recommend improvement options and future requirements for using R/USLE models in Morocco.

\section{R/USLE models}

USLE origin's the United States Department of Agriculture (USDA). It is an empirical model used to assess soil erosion. This model was developed by Wischmeier and Smith [1] based on the results of controlled studies on field plots and small watersheds research. Erosion form that can be predicted by this model is sheet/inter-rill and small rill erosion. It cannot estimate the other erosion forms like riverbanks and riverbed [1]. The USLE equation was defined as a product of five input factors: rainfall erosivity, soil erodibility, slope length and steepness, cover management, and support practice. This multiplicative function is formulated as follows:

$$
A=R * K^{*} L S^{*} C * P
$$

Where $\mathrm{A}$ is the mean annual soil loss (t. ha-1 $\mathrm{yr}-1$ ), $\mathrm{R}$ is a rainfall erosivity factor (MJ mm. ha-1.h-1. yr-1), $\mathrm{K}$ is a soil erodibility factor ( $\mathrm{t}$ ha h ha-1 MJ-1 mm-1), $\mathrm{C}$ is a dimensionless cover and management factor, $\mathrm{P}$ is a dimensionless erosion control practice factor, LS is a topographic factor.

\footnotetext{
Corresponding author: mmanaouch@gmail.com
} 


\subsection{Data assessment}

In order to assess the conducted R/USLE studies in Morocco, the published literature was collected, classified and evaluated. The methodology consists of the following steps:

- Setting a time frame of required data. Data were collected from published documents related to R/USLE applications in Morocco from 1970 when the first studies of soil erosion started till date 2020,

- Framing questions, four main questions were taken into consideration; How many documents were published related to R/USLE in Morocco? What type of documents? Where were the studies? And what is the results?

- Identifying search criteria and conducting search. Search was done on "Web of Science", Science direct", "Scopus", "Google", "Google scholar" and "Research gate" using the keywords "Morocco", "soil erosion" and "USLE or RUSLE",

- Screening records, classification and evaluation of collected data. The classification and evaluation would consider published documents such as "research papers" and "review papers" published in local journals, international journals or conference proceedings. Documents should be related to USLE or RUSLE in Morocco published during the period from 1970 to 2020.

\subsection{History of the soil erosion studies and R/USLE models applications in Morocco}

Several soil erosion studies have been carried out on a national scale, the first was done in the Prerif. It was an experimental station established by Heusch and Kalman [2] in the wadi Mda watershed. Then, two groups in the early 1990 have studied soil erosion, the first group have focused on three different sites: the Oriental, central Rif and Maamoura forest. In parallel with the first group, engineers from the soil department of the I.A.V. (Hassan II Agronomic and Veterinary Institute), and the E.N.F.I. (National School of Forest Engineers) did many studies and experimental research for their final theses, using geographic information systems and satellite images and based on experimental plots, small sub-watersheds and on the rain simulation.

During the 1990s, regional centers for watersheds studies and development, as part of the project MOR/93/010 financially supported by the Food and Agriculture Organization (FAO), have set up a network of 74 experimental plots, aimed to quantify soil erosion and to adapt the revised USLE to Moroccan environmental conditions by integrating climatic, soil, topographic and agricultural techniques in the RUSLE program database.

During the nineties and after 2000 several studies on soil erosion involving different methods concerning the western or eastern Rif and the Atlantic slopes of the Middle and High Atlas.

\subsection{Geographical distribution of the R/USLE studies in Morocco}

R/USLE modeling publications related to Morocco were done in five regions as shown in Figure 2. The Rif and
Prerif were the main subjects of publications, accounting for $50 \%$ of the total published documents. Publications in this area include assessments of soil erosion in several case studies (Western Rif, Eastern Rif, Central Rif and Prerif) where the environmental impacts of soil erosion have been observed such as siltation of dams, decrease in water quality and loss of soil fertility. Since, the magnitude of soil erosion is very important in these areas (Rif and Prerif) which cover only $6 \%$ of the national territory but which produce $60 \%$ of sediment [2]. In the Rif mountains and hills, the soil loss average reaches $20 \mathrm{t}$. ha- 1 . yr- 1 , while it is only 5 to $10 \mathrm{t}$. ha-1. yr-1 in the Middle and High Atlas [3]. However, R/USLE studies in this area so far have focused only on the modeling of soil erosion in the same watersheds by many authors without studying the other basins. So, this remark should be taken into consideration.

R/USLE applications related to the High Atlas areas (region with the highest mountain peaks in North Africa) represented $21.4 \%$ of the total publications. The conducted studies addressed the environmental impacts of soil erosion and dam siltation. These studies dealt with determining the sediment production rates in separate areas that included the middle and eastern High Atlas and some regions in the far western High Atlas.

For the Moroccan Meseta, the R/USLE studies represented $14.3 \%$ of the total publications. These studies have focused on the environmental impacts of soil erosion. Both for the Middle Atlas watersheds and for the Oriental region, only $7.1 \%$ of RULE's publications represented.

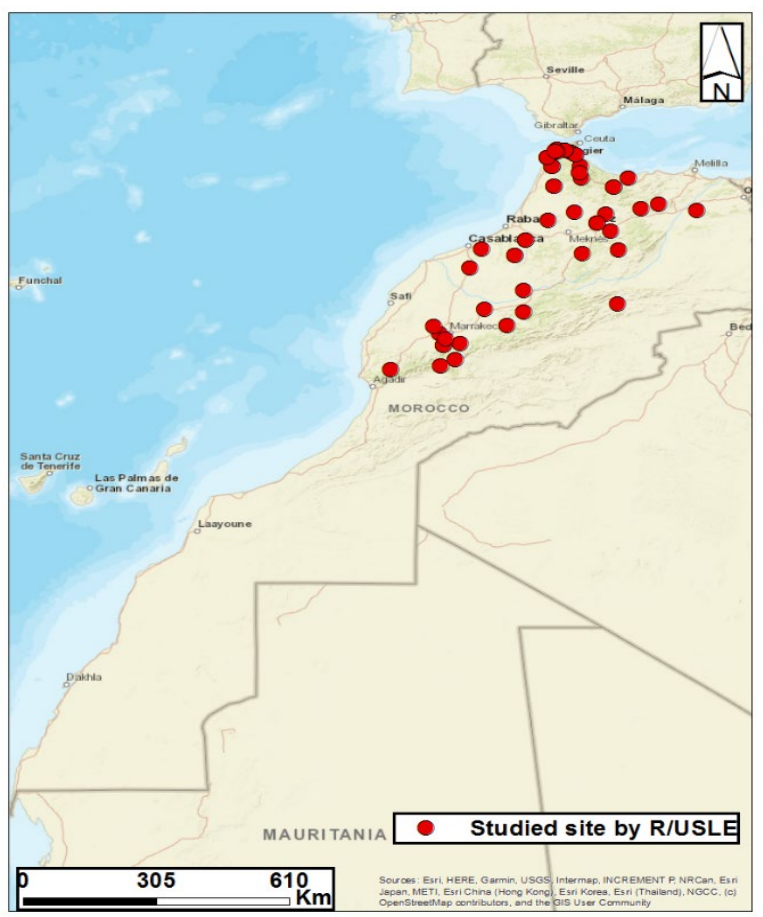

Fig. 1. Geographic distribution of published papers using R/USLE modeling from 1987 to May 2020.

\subsection{Overview on R/USLE Publications Related to Morocco}

The summary of published documents related to $\mathrm{R} / \mathrm{USLE}$ model's applications in Morocco is presented in 
Table 1 and Figure 2. It was found that 56 publications documents were concerned on R/USLE studies in Morocco. Fifty papers were in the Rif and Prerif.

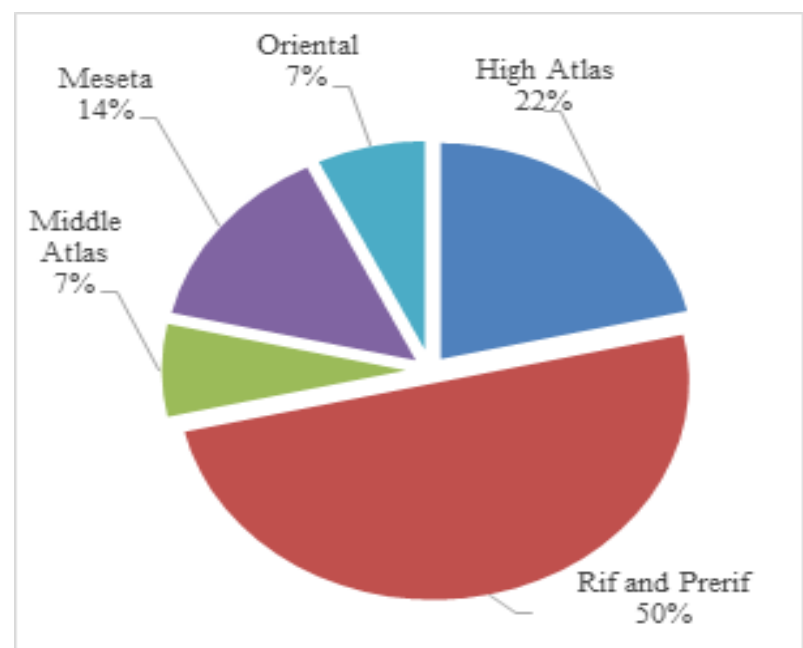

Fig. 2. Percentage of R/USLE models applications per covered area from 1987 to 2020

Table 1. Summary of R/USLE studies in Morocco published from 1987 to May 2020.

\begin{tabular}{|c|c|c|}
\hline $\begin{array}{l}\text { Study } \\
\text { area }\end{array}$ & $\begin{array}{l}\text { Number of } \\
\text { publications } \\
\text { (Indexed } \\
\text { journals) }\end{array}$ & Affiliation \\
\hline $\begin{array}{l}\text { Rif and } \\
\text { Prerif }\end{array}$ & 28 & $\begin{array}{c}\text { Abdelmalek Essaadi university (7) } \\
\text { Chouaib Doukkali university (1) } \\
\text { Hassan II university (4) } \\
\text { Moulay Ismail university (1) } \\
\text { Sidi Mohamed Ben Abdellah } \\
\text { university (6) } \\
\text { ENFI : Ecole Nationale Forestiere } \\
\text { d'Ingenieurs (3) } \\
\text { IAV : Institut Agronomique et } \\
\text { Vétérinaire (2) } \\
\text { Ibn Tofail university (1) } \\
\text { Mohamed V university (2) } \\
\text { Cadi Ayyad university (1) }\end{array}$ \\
\hline $\begin{array}{c}\text { Middle } \\
\text { Atlas }\end{array}$ & 4 & $\begin{array}{c}\text { Moulay Ismail university (1) } \\
\text { Sidi Mohamed Ben Abdellah } \\
\text { university (1) } \\
\text { Sultan My Slimane university (2) }\end{array}$ \\
\hline $\begin{array}{l}\text { High } \\
\text { Atlas }\end{array}$ & 12 & $\begin{array}{c}\text { Ibn Zohr university (1) } \\
\text { Hassan II university (1) } \\
\text { Moulay Ismail university (1) } \\
\text { Sultan My Slimane university (1) } \\
\text { Institut Agronomique et } \\
\text { Vétérinaire (1) } \\
\text { Ibn Tofail university (1) } \\
\text { Mohamed V university (3) } \\
\text { Cadi Ayyad university (4) }\end{array}$ \\
\hline Oriental & 4 & $\begin{array}{c}\text { Abdelmalek Essaadi university (1) } \\
\text { Sidi Mohamed Ben Abdellah } \\
\text { university (2) } \\
\text { Mohamed V university (1) }\end{array}$ \\
\hline Meseta & 8 & $\begin{array}{l}\text { Moulay Ismail university (1) } \\
\text { Ibn Tofail university (1) } \\
\text { Mohamed V university (3) } \\
\text { Hassan 1 er university (2) } \\
\text { IAV : Institut Agronomique et } \\
\text { Vétérinaire (1) }\end{array}$ \\
\hline
\end{tabular}

Most of the documents (84\%) were published in international peer- reviewed journals, a few in a national paper (14\%) and only $2 \%$ in conference proceedings.

Most of the conducted studies were done by national universities researchers and research institutes and centers (as shown in Figure 3). Only some research studies by foreign researchers. This reflects the need to promote R/USLE models as a soil erosion tool within the other Moroccan landscapes.

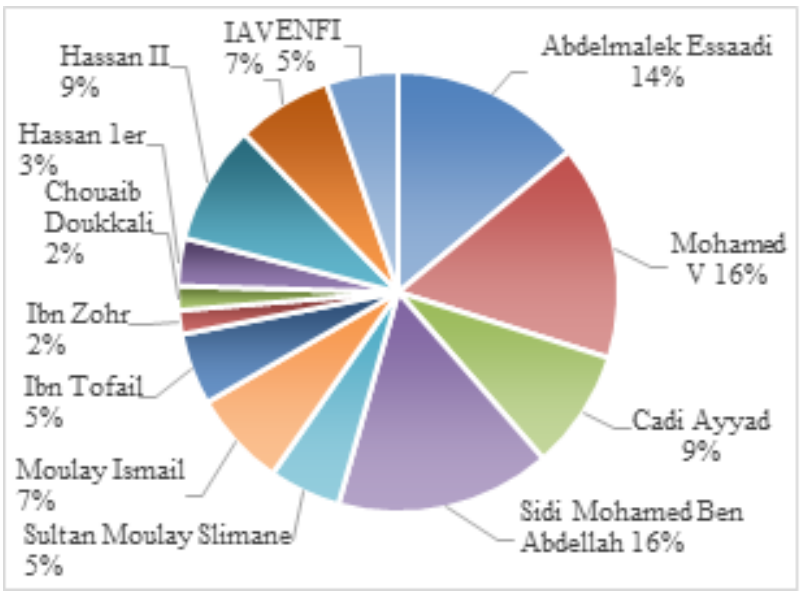

Fig. 3. Percentage of R/USLE applications studies per affiliation from 1987 to May 2020.

R/USLE applications were published in a wide variety of journals. The fifty peer reviewed papers have been published in more than 30 indexed journals with the highest frequency in Scopus database (30\%), followed by the Web of Science database, Springer, the Journal of Geographic Information System, the Journal of Geography, Environment and Earth Science International, the International Journal of Geosciences and "Bulletin de l'Institut Scientifique, Section Sciences de la Terre " $(3.3 \%)$. More than $84 \%$ of the papers are classified as research articles, followed by national paper $(14 \%)$ and conference papers $(2 \%)$, book chapters $(0 \%)$ and review papers $(0 \%)$.

As shown in Figure 4, the published papers distribution yielded a strongly increasing trend with the highest number of published articles (7) in 2018 and 2019. A sharp increase in publication rates started in the late 2012.

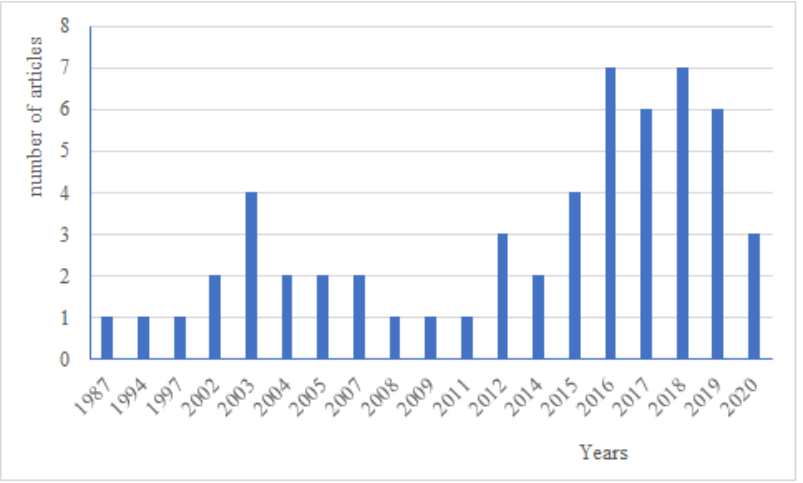

Fig. 4. Trend of the R/USLE published papers from 1987 to May 2020. 


\subsection{Methods used for estimating R/USLE factors from various studies}

Although, the R/USLE application seem to be a simple product of five factors at first glance, this section addresses the alternatives equations that go into calculating its factors, such as $\mathrm{R}$ factor which requires rainfall data of 30 minute. For that, this review discusses the measures that future users should consider before applying the R/USLE models.

\section{Results and Discussions}

In this section, we discuss different methods used to estimate the R/USLE factors (R, K, LS, C and P). Different R/USLE applications were collected and analysed to compile how they adapted R/USLE factors to the Moroccan conditions.

\subsection{Rainfall erosivity factor $(R)$}

Wischmeier (1959) defined a "Rainfall Erosion Index" as a product of the total kinetic energy of the storm and its maximum 30-min intensity $\left(\mathrm{EI}_{30}\right)$. So, the estimation of $\mathrm{R}$ factor according to the R/USLE formula requires knowledge of the kinetic energy and rain average intensity. The lack of meteorological stations with 30 min data for long-periods and measured rainfall intensity, Scientists and researchers forced to evolve some empirical equations correlating R-factor with available rainfall data. So, in the R/USLE applications in Morocco, many researchers' have either applied different equations for estimating erosivity (R-factor) or have proposed empirical erosivity equations such as the Arnoldus (1980) ]4] and its modification by Rango \& Arnoldus (1987) ]5].

Table 2. Summary of the R-factors equations used in the $\mathrm{R} / \mathrm{USLE}$ previous studies in Morocco

\begin{tabular}{|c|c|c|c|c|c|c|c|c|c|c|}
\cline { 2 - 10 } \multicolumn{1}{c|}{} & A & B & C & D & E & F & G & H & I & J \\
\hline $\mathrm{R}$ & 18 & 12 & 2 & 1 & 1 & 2 & 19 & 1 & 1 & 1 \\
\hline$\%$ & $\begin{array}{c}31 . \\
0\end{array}$ & $\begin{array}{c}20 . \\
7\end{array}$ & $\begin{array}{c}3 . \\
4\end{array}$ & $\begin{array}{c}1 . \\
7\end{array}$ & $\begin{array}{c}1 . \\
7\end{array}$ & $\begin{array}{c}3 . \\
4\end{array}$ & $\begin{array}{c}32 . \\
8\end{array}$ & $\begin{array}{c}1 . \\
7\end{array}$ & $\begin{array}{c}1 . \\
7\end{array}$ & \begin{tabular}{c}
7 \\
\hline
\end{tabular}
\end{tabular}

A: Arnoldus; B: Arnoldus \& Rango; C: Brown and Foster (1987); D: Cortés (1991); E: Literature; F: Modified Fournier Index; G: Not available; H: Renard (1996); I: Tropical Rainfall Measuring Mission (TRMM); J: WorldClim 1.4

In this review, $51.7 \%$ of the $\mathrm{R}$ factor assessment was based on the equation of Arnoldus (1980) ]4] and Rango and Arnoldus (1987) ]5]. These equations which use monthly and annual precipitation have been developed in Morocco and in other places in West Africa.

For future R/USLE applications, it should be noted that a group of scientists has collected data on rainfall erosivity from more than three thousand meteorological stations in over sixty countries and established the Global Rainfall Erosivity Database (GloReDa) ]6].

\subsection{Soil erodibility factor (K)}

This parameter measures the susceptibility of soil particles to detachment under raindrops impact or runoff or a combination of both. Soil physical parameters, particularly organic matter, clay, structure and permeability, are decisive for keeping tolerable erodibility rates. Some studies have revealed that the effect of stoniness reduces the soil erodibility by 20 to $40 \%$ in Mediterranean soils.

Given the absence of a soil studies in all the Moroccan territory, some R/USLE studies estimate the K factor parameters based on different results such as the Wischmeier nomograph and some previous studies.

Table 3. Summary of the K-factors formulas used in the $\mathrm{R} /$ USLE previous studies in Morocco

\begin{tabular}{|lll|l|l|l|l|l|l|l|l|l|}
\hline \multicolumn{1}{c|}{} & A & B & C & D & E & F & G & H & I & J & K \\
\hline $\mathrm{K}$ & 3 & 5 & 7 & 17 & 3 & 1 & 16 & 1 & 1 & 1 & 1 \\
\hline$\%$ & $\begin{array}{l}5 . \\
4\end{array}$ & $\begin{array}{l}8 . \\
9\end{array}$ & $\begin{array}{l}12 . \\
5\end{array}$ & $\begin{array}{l}30 . \\
4\end{array}$ & $\begin{array}{l}5 . \\
4\end{array}$ & $\begin{array}{l}1 . \\
8\end{array}$ & $\begin{array}{l}28 \\
6\end{array}$ & $\begin{array}{l}1 . \\
8\end{array}$ & $\begin{array}{l}1 . \\
8\end{array}$ & $\begin{array}{l}1 . \\
8\end{array}$ & $\begin{array}{c}1 \\
8\end{array}$ \\
\hline
\end{tabular}

A: Hamonized World Soil Database (HWSD); B: Literature; C: Merzouk 1985; D: USLE method; E: Sharpley and Williams; F: Schwertmann et al. (1987); G: Non available; H: Previous studies; I: USLE and Tribak; J: USLE and Dumas; K: Soil analysis

Generally, the USLE nomograph should only be used if there is not a locally derived relationship or measured data that would also account for seasonal changes in the $\mathrm{K}$-factor. In this review, because of a lack of measured plot data, $52 \%$ of the K-factor estimation was based on three sources: the USLE method, Merzouk works (1985) ]7] and Literature.

Currently, the use of remote sensing data as well as large-scale databases offer new opportunities to estimate $\mathrm{K}$ factor in space and time. Several studies have already used the hyperspectral reflectance of soil surfaces to assess the soil chemical and physical properties.

\subsection{Topographic factor (LS): Slope length (L) and steepness (S)}

The two topographic parameters that control erosion are the slope length and the steepness. The more their values increase, the more active the erosion on the slopes, and the higher the runoff, hence the high risk of flooding.

The USLE was firstly developed to predict soil loss on uniform slopes and fields. The first physically based slope length factor was developed by Moore and Burch (1986). Then, it was proposed that the unit contributing area which is the upslope drainage area per unit of contour length should substitute slope length ]8]. So, The LS factor was replaced by the upslope contributing area 
in various forms. Currently, four algorithms exist to calculate the upslope contributing area.

Table 4. Summary of the LS-factor formulas used in the $\mathrm{R} / \mathrm{USLE}$ previous studies in Morocco

\begin{tabular}{|l|l|l|l|l|l|l|l|l|l|l|}
\cline { 2 - 10 } \multicolumn{1}{c|}{} & A & B & C & D & E & F & G & H & I & J \\
\hline $\begin{array}{l}\text { L } \\
\text { S }\end{array}$ & 7 & 5 & 11 & 1 & 2 & 1 & 16 & 2 & 1 & 8 \\
\hline$\%$ & $\begin{array}{l}13 . \\
0\end{array}$ & $\begin{array}{l}9 . \\
3\end{array}$ & $\begin{array}{l}20 . \\
4\end{array}$ & $\begin{array}{l}1 . \\
9\end{array}$ & $\begin{array}{l}3 . \\
7\end{array}$ & $\begin{array}{l}1 . \\
9\end{array}$ & $\begin{array}{l}29 . \\
6\end{array}$ & $\begin{array}{l}3 . \\
7\end{array}$ & $\begin{array}{l}1 . \\
9\end{array}$ & $\begin{array}{l}14 . \\
8\end{array}$ \\
\hline
\end{tabular}

A: R/USLE; B: Bizuwerk; C: Mitasova; D: Dahman; E: Moore and Burch; F: Foster 1977 McCool 1987; G: Not available; H: Desmet and Govers, 1996; I: Velásquez 2013; H: Geographic Information System (GIS) procedure.

According to the review's results, Mitasova's formula was the first applied in R/USLE applications.

\subsection{Cover and management factor (C)}

In the last years, the most common methods of calculating $\mathrm{C}$-factor are the simple attribution of $\mathrm{C}$-factor literature values to land use maps or satellite image classification. Recently, the calculation of C-factor at the regional scale is based on remote sensing techniques and this approach has become widely applied.

Table 5. Summary of the C-factor equations used in the $\mathrm{R} / \mathrm{USLE}$ previous studies in Morocco

\begin{tabular}{|c|c|c|c|c|c|c|c|c|}
\hline & $\mathbf{A}$ & B & C & D & $\mathbf{E}$ & $\mathbf{F}$ & $\mathbf{G}$ & $\mathbf{H}$ \\
\hline $\mathrm{C}$ & 3 & 14 & 11 & 2 & 3 & 6 & 18 & 2 \\
\hline$\%$ & 5.1 & 23.7 & 18.6 & 3.4 & 5.1 & 10.2 & 30.5 & 3.4 \\
\hline
\end{tabular}

A: Feild observation; B: Satelite image classification; C: Literature; D: Previous study; E: RUSLE Data Base; F: Normalized Difference Vegetation Index (NDVI) Van der Knijff; G: Not available; H: Desmet and Govers

In this review, $53 \%$ of the $\mathrm{C}$ factor was computed by the image classification, from literature and NDVI using the regression relation of Van der Knijff (2000)] 9].

\subsection{Support practice factor (P)}

P-factor is a parameter that allows consideration of existing anti-erosion practices in the estimation of soil losses. Typical $\mathrm{P}$ values range from about 0.2 for reverse-slope bench terraces to 1.0 where there are no erosion control practices ]10].

With the transition from field modeling to a largescale using GIS techniques, the lack of spatial information to compute P-factor means that this factor has been omitted. Nevertheless, the large-scale studies suggested alternative methods that can provide relative estimations of the $\mathrm{P}$ factor.
Table 6. Summary of the P-factor values used in the R/USLE previous studies in Morocco

\begin{tabular}{|c|c|c|c|c|c|c|c|c|c|}
\cline { 2 - 9 } \multicolumn{1}{c|}{} & $\mathbf{A}$ & $\mathbf{B}$ & $\mathbf{C}$ & $\mathbf{D}$ & $\mathbf{E}$ & $\mathbf{F}$ & $\mathbf{G}$ & $\mathbf{H}$ & $\mathbf{I}$ \\
\hline $\mathrm{P}$ & 22 & 23 & 3 & 1 & 1 & 2 & 1 & 1 & 1 \\
\hline$\%$ & 38.6 & 40.4 & 5.3 & 1.8 & 1.8 & 3.5 & 1.8 & 1.8 & 5.3 \\
\hline
\end{tabular}

A: Not available; B: None observed $(\mathrm{P}=1)$; $\mathrm{C}$ : Literature; D: Roose (1996); E: Shin (1999); F: Van der Knijff (2000); G: Laouina (2007); H: GLOBCOVER I: Previous study

In this review, $40 \%$ of $\mathrm{P}$ factor studies used the value of 1 and $10 \%$ of $\mathrm{P}$ factor estimations are based on previous studies and literature.

\section{R/USLE models can help us protect the environment}

Soil erosion cause many environmental and socioeconomic problems on -and off-site: loss of biodiversity, reduce productivity of agricultural land by removing fertile topsoil, dam's siltation, increased risk of flooding, so there is a need to take preventive measures. Soil erosion modeling proved to be an efficient tool for researchers, policymakers who want to protect the environment.

In Morocco, R/USLE models has adopted for estimating the potential soil erosion risk in many parts. But unfortunately, these studies have been used available data for estimating R/USLE factors (RKLSCP). Since, some of these factors are the driving forces of soil loss rates, their estimation should be made correctly. In this context, the present review aimed to analyze R/USLE factors formulas used for each study and related improvement and future need were illustrated. The review's results showed that the main challenge that face further usage of R/USLE models is the lack of local data.

Data limitations, in terms of unavailability of recent local data for conducting the R/USLE's researches and for benchmarking of results is a challenging point for consideration. The availability of local data is a key factor for conducting any R/USLE models application.

The review's findings can be used to guide future research, extend research results and help environmentalists to manage soil erosion risks if researchers pay more attention to applying R/USLE models correctly. The predicted soil loss maps of the correct R/USLE applications can constitute a road map for future soil erosion projects and a useful tool for proposing soil conservation strategies.

\section{R/USLE models validation}

R/USLE models validating is usually made with measured data. But the major problem is that these models provides gross erosion rate while most measurement of erosion on-site or off-site provides net erosion. So, the modelled and measured data has to be 
scrutinized when R/USLE models' validation with measured data is aimed.

On-site, there are two types of soil erosion measurement; the direct methods as soil erosion assessment in plots which implies a long term monitoring all year round and the indirect assessment using fallout radionuclides (FRN) as tracers of soil erosion.

Based on the $137 \mathrm{Cs}$ soil erosion tracer measurements, it was concluded that USLE applications estimates were less accurate and more biased than some other empirical models such as the Unit Stream Power Erosion and Deposition (USPED) model ]11].

For R/USLE models validation in morocco, most cases are based on comparison of results with those measured at the outlet. Because a comparison of RUSLE model for some Mediterranean regions demonstrated its feasibility to estimate the spatial distribution of soil loss at the watershed scale and a good match with the measured silting data] 12].

Recently, RUSLE model was combined with sediment transport and delivery processes which describes not only soil erosion risk, but also considers sediment transport.

A similar approach is followed with the Sediment Delivery Distributed Modell (SEDD) where RUSLE model is used to calculate gross erosion rates then coupled to a sediment delivery tool to assess net sediment transport and delivery on catchment scale] 13].

\section{Limits of R/USLE models}

Many authors criticize the misuse of the R/USLE models under outside of the United States of America (USA) where it was developed. The USLE was developed in landscapes of peneplains on slopes of less than $20 \%$ where it is mainly the kinetic energy of raindrops that causes particles to detach. While in the mountains on slopes greater than $40 \%$ runoff is a greater source of energy than rain. Thus, when it applies to different conditions, it can result in an overestimation or underestimation of the actual average annual soil loss ]14].

Furthermore, the original USLE model and its factors were developed for plot scale of $22.1 \mathrm{~m}$ length. Thus, there are precautions associated when using the original USLE in a larger scale such as watershed or regional scale ]15].

Another R/USLE limitation often cited is related to the type of erosion that quantifies, it estimates only sheet and rill erosion] 16]. So, many authors say that R/USLE is not applicable in a catchment area to estimate the dam's lifetimes because it underestimates the erosion rates since it doesn't take into account other erosion forms which can be particularly intense] 17]. The model can also overestimate erosion because it doesn't account for the redistribution of particles in the basin (temporary deposition of slopes or fluviatile which can be considerable and last several thousand years).
Despite these disadvantages, the R/USLE models are still widely used because of their simplicity and little data requirements compared to other models.

\section{Conclusion}

This paper reviews the different components of the USLE and its updated form, the RUSLE. Different R/USLE studies around the Moroccan areas were collected and analyzed to compile how they adapted $\mathrm{R} / \mathrm{USLE}$ to their unique conditions. R/USLE models proved to be an efficient tool for researchers, scientists who want to study soil erosion modeling. This important tool should be employed in Moroccan studies more frequently.

Main gaps of each method of R/USLE factors estimation and related improvement and future need of studies were illustrated. The main challenges that face further usage of R/USLE models as a tool for soil erosion modelling in Morocco were the lack of local data and the awareness about this important tool limits its utilization. Data limitation, in terms of unavailability of recent local data for conducting the researches and for benchmarking the results. The availability of data is a key factor for conducting any R/USLE application.

For that, data has to be collected from case studies by the research group that could be subjected to some uncertainty. The scientific events such as conferences can be organized to promote the advantages of R/USLE models on how to use it correctly and to establish links between international experts in this field.

This paper presented some of the limitations of the $\mathrm{R} / \mathrm{USLE}$ and outlined a few future directions.

\section{References}

1. W.H. Wischmeier, D.D. Smith, Predicting rainfall erosion losses: a guide to conservation planning, USDA Handbook, 537, 58 (1978)

2. B. Heusch, L'érosion du pré-Rif, une étude quantitative de l'érosion hydraulique dans les collines marneuses du pré-Rif Occidental, Ann. Rech. Forest. Maroc 12, 9-176 (1970)

3. AEFCS Morocco, Administration des Eaux et Forêts et de la Conservation des Sols -Plan National d'Aménagement des Bassins Versant (P. N. A. B. V.) p.17.(1999)

4. H.M.J. Arnoldus, Methodology used to determine the maximum potential average soil loss due to sheet and rill erosion in Morocco, FAO 34, 39-48 (1980)

5. A. Rango, H.M.J. Arnoldus, Aménagement des bassins versants, Cahiers techniques de la FAO 36, (1987)

6. P. Panagos, P. Borrelli, K. Meusburger, B. Yu, A. Klik, K.J. Lim, et al., Global rainfall erosivity assessment based on high-temporal resolution rainfall records, Sc. Reports, In review (February), $1-12(2017 b)$ 
7. A. Merzouk, Relative erodibility of nine selected Moroccan soils related to their physical and chemical and mineralogical properties, (University.of Minnesota, USA, 1985)

8. P. Desmet G. Govers, A GIS procedure for automatically calculating the USLE LS factor on topographically complex landscape units, JSWC 15(5), 427-433 (1996)

9. J.M. Van der Knijff, R.J.A. Jones, L. Montanarella, Soil erosion risk assessment in Italy, ESBJRC of the European Commission 54, (1999)

10. W.H. Wischmeier, D.D. Smith, Predicting rainfall erosion losses: a guide to conservation planning, USDA Handbook, 537, 58 (1978)

11. S.D. Warren, H. Mitasova, M.G. Hohmann, S. Landsberger, F.Y. Iskander, T.S. Ruzycki et al., Validation of a 3-D enhancement of the Universal Soil Loss Equation for prediction of soil erosion and sediment deposition, Catena 64(2-3), 281-296 (2005)

12. A. Aiello, M. Adamo, F. Canora, Remote sensing and GIS to assess soil erosion with RUSLE3D and USPED at river basin scale in southern Italy, Catena, 131, 174-185 (2015)

13. V. Ferro, P. Porto, Sediment delivery distributed (SEDD) model, JHE, 5(4), 411-422 (2000)

14. P.I.A. Kinnell, Event soil loss, runoff and the universal soil loss equation family of models: A review, JH 385(1-4), 384-397 (2010)

15. V. Naipal, C. Reick, J. Pongratz, K. Van Oost, Improving the global applicability of the RUSLE model - Adjustment of the topographical and rainfall erosivity factors, Geosci. Model Dev. 8(9), 2893-2913 (2015)

16. C.R. Thorne, L.W. Zevenbergen, E.H. Grissinger, J.B. Murphey, Calculator programe and nomograph for on-site predictions of ephemeral gully erosion, (1985)

17. E. Roose, Introduction à la gestion conservatoire de l'eau et de la fertilité des sols stratégie naturelle de lutte anti-érosive, G.C.E.S. Projet de Bulletin des sols de la FAO, Rome, 210 (1994). 